\title{
Reduction of Sample Volume and Waste Generation in Acid/Base Titrations Using Microelectrodes
}

by

A. A.Ekechukwu

Westinghouse Savannah River Company

Savannah River Site

Aiken, South Carolina 29808

RECEIVED

Jע木 211996

OSTI

This paper was prepared in connection with work done under the above contract number with the U.S. Department of Energy. By acceptance of this paper, the publisher and/or recipient acknowledges the U. S. Government's right to retain a nonexclusive, royalty-free license in and to any copyright covering this paper, along with the right to reproduce and to authorize others to reproduce all or part of the copyrighted paper. 


\section{DISCLAIMER}

Portions of this document may be illegible in electronic image products. Images are produced from the best available original document. 


\section{DISCLAIMER}

This report was prepared as an account of work sponsored by an agency of the United States Government. Neither the United States Government nor any agency thereof, nor any of their employees, makes any warranty, express or implied, or assumes any legal liability or responsibility for the accuracy, completeness, or usefulness of any information, apparatus, product, o $\dot{\xi}$ - process disclosed, or represents that its use would not infringe privately owned rights. Reference herein to any specific commercial product, process, or service by trade name, trademark, manufacturer, or otherwise does not necessarily constitute or imply. its endorsement, recommendation, or favoring by the United States Goverament or any agency thereof. The views and opinions of authors expressed herein do not necessarily state or reflect those of $\cdot$ the United. States -Government or any agency thereof.

This report has been reproduced directly from the best ayailable copy.

$\because$

Available to DOE and DOE contractors from the Office of Scientific and Technical Information, P. O. Box 62. Oak Ridge, TN 37831; prices available from (615) $576-8401$.

Available to the public from the National Technical Information Service. U. S. Deparment of Commerce, 5285 Port Royal Rd., Springfield, VA 22161 
March 1, 1996

Keywords:

titration, $\mathrm{pH}$, acid, base, microelectrodes,

Retention Time Permanent

\title{
REDUCTION OF SAMPLE VOLUME AND WASTE GENERATION IN ACD/BASE TITRATIONS USING MICROELECTRODES (u)
}

\author{
A. A. Ekechukwu
}

\section{SUMMARY}

The Analytical Development Section (ADS) has developed microelectrode methods for use with $\mathrm{pH}$ titrations and $\mathrm{pH}$ determinations. These microelectrode methods offer increased sensitivity and enable analyses to be done with smaller sample and buffer volumes than are used with standard size electrodes. This report establishes the technical validity of the methods and describes the application of these methods to decreased detection limits, decreased waste generation, and decreased radiation exposure.

\section{INTRODUCTION}

Hydrogen ion concentration, $\mathrm{pH}$, is one of the most frequently made measurements in the ADS Wet Chemistry laboratory. In addition to the absolute measurement of solution $\mathrm{pH}$, many of the analyses performed in the wet chemistry laboratory are titrations which use $\mathrm{pH}$ to determine the titration endpoint. The measurement of total and free acid, total and free base, aluminate, carbonate, and alkalinity all use solution $\mathrm{pH}$ to determine the endpoint of titration. In a typical $\mathrm{pH}$ titration, an aliquot of sample is added to a volume of buffer or water. The $\mathrm{pH}$ of this solution is monitored as titrant, a standardized acid or base, is added. The "break-point" (region where the $\mathrm{pH}$ of the solution changes rapidly) of the titration is noted, and the analyte concentration is calculated from the concentration of the titrant and the volume of titrant used to reach the break-point. The titration curve for a typical pH titration, determination of total hydroxide concentration, is shown in Figure 1.

Although the measurement of absolute $\mathrm{pH}$ is one of the simplest laboratory analyses, it is frequently done incorrectly, particularly with unbuffered samples. The most commonly made error is not allowing the electrode to equilibrate sufficiently in the 
WSRC-RP-96-83

Page 2 of 6

sample. Therefore it is important to measure an adequate sample volume (20 to 25 $\mathrm{mL}$ with a standard size $12 \mathrm{~mm}$ electrode) and to repeat the measurement with fresh volumes of sample until successive measurements agree within $0.1 \mathrm{pH}$ unit. In general, 50 to $100 \mathrm{~mL}$ of sample are required to accurately determine $\mathrm{pH}$. Since the required sample volume is proportional to the size and sensitivity of the electrode, reduction of the solution volume and generated waste can be accomplished by using smaller, more sensitive electrodes known as microelectrodes.

Microelectrodes are small working surface electrodes, ranging in size from $5 \mathrm{~mm}$ to less than $1 \mathrm{~mm}$ in diameter. A standard size electrode, which is usually $12 \mathrm{~mm}$ in diameter, typically requires clearance in solution of twice the electrode diameter in order to obtain accurate data. If a smaller solution volume is used, the electrode experiences electrochemical feedback from the sides of the reaction vessel. This feedback distorts the electrochemical response and corrupts the acquired data. Smaller electrodes require proportionally less clearance in solution and thus smaller volumes of solution. In addition, reducing the size of the electrode surface decreases the electrochemical noise caused by the unequal distance of all points on the surface of the electrode to the reference or counter electrode. For these reasons, smaller electrodes offer lower detection limits and require correspondingly lower sample volumes. ADS made use of these microelectrodes to decrease the analysis system size and enhance the sensitivity of the $\mathrm{pH}$ measurements and $\mathrm{pH}$ titrations performed in the lab.

\section{EXPERIMENTAL}

\section{Equipment Description}

$\mathrm{pH}$ measurements for $\mathrm{pH}$ determinations were made using a Beckman IS12 pH Meter. The electrode used was a Beckman Futura $4 \mathrm{~mm}$ combination $\mathrm{pH}$ electrode. For titrations, a Radiometer Autotitration system was used with a Radiometer model pHC4400 combination pH electrode. The term "combination" refers to an electrode which incorporates both the working electrode and the reference electrode in one unit.

\section{Standards and Calibration}

The measuring systems were calibrated using National Institute of Standards Technology (NIST) traceable buffers, $\mathrm{pH} 4$ and $\mathrm{pH}$ 7. Check standards, listed in Table 1, were prepared and analyzed to verify the validity of the $\mathrm{pH}$ calibration.

\section{Length of Time Required for Analysis}

For titrations, the length of time required for analysis depends upon the amount of analyte present in the sample to be titrated. In titration methods performed in the ADS wet chemistry lab, the maximum volume of titrant is expended in 5 minutes. Samples which are more concentrated and require additional titrant are diluted and reanalyzed. In general, a titration takes 1 to 4 minutes to complete. In $\mathrm{pH}$ determinations, the electrode stabilizes in solution in less than one minute. Generally three to four successive determinations are required to obtain an accurate reading. 


\section{Accuracy and Precision of Measurements}

Using the calibration standards listed above, the precision of the titration methods and $\mathrm{pH}$ measurement is between $+/-1$ and $3 \% \mathrm{RSD}$. This is comparable to precision using the standard size electrode. The precision and accuracy are dependent upon the sample matrix so may be slightly higher for actual samples. Table 1 shows the results for check standards and $\mathrm{pH}$ buffers run with the various titration methods.

\section{DISCUSSION}

\section{pH Titrations}

The titration vessel used with the standard size $\mathrm{pH}$ electrode required a minimum sample volume of $25 \mathrm{~mL}$ to adequately cover the surface of the electrode. Using a narrower microelectrode, the analysis could be performed in a $10 \mathrm{~mL}$ titration vessel which requires only $5 \mathrm{~mL}$ of sample to adequately cover the electrode surface. Data validation tests on standards and samples showed the precision and detection limits to be comparable to that obtained using a standard size electrode and $25 \mathrm{~mL}$ of solution. Table 2 shows the results of five samples which were analyzed using both the standard size electrode and the microelectrode. The results are equivalent within the accuracy of the method $(+/-3 \%)$.

\section{pH Measurement}

The standard size $\mathrm{pH}$ electrode which had been in use in the lab required 20 to $25 \mathrm{~mL}$ of solution to adequately cover the electrode. The $4 \mathrm{~mm}$ diameter microelectrode requires only $5 \mathrm{~mm}$ clearance to generate accurate data. Using a $10 \mathrm{~mL}$ vial, accurate $\mathrm{pH}$ measurements can be made using $1.5 \mathrm{~mL}$ of sample. Table 3 shows the data for five samples and buffer standards. The $\mathrm{pH}$ results agreed within $0.1 \mathrm{pH}$ unit and so are considered essentially equivalent within the precision of the method.

\section{Comparison of Standard Size and Microelectrodes}

Aside from the obvious size difference, standard and microelectrodes differ in sensitivity and accuracy. Ideal electrochemical behavior (referred to as a Nernstian response) is obtained with a point-to-point interaction between the electrodes in a cell. As the surface of the electrode expands and becomes more than a point, this ideal response is distorted. An analogous situation is found in spectrophotometry. As the grating used to distinguish between wavelengths becomes larger, there is less definition between wavelengths and thus less resolution in the measurement. Since noise effects smaller measurements more, this distortion increases the detection limits. Microelectrodes are accurate in the nanoamp and even picoamp range whereas standard size electrodes are accurate only in the milliamp to microamp range.

The increase in sensitivity comes at a cost of durability of the electrode. Microelectrodes are physically more fragile than their standard size counter parts. They are therefore not well suited to field work. Microelectrode surfaces are more easily fouled (coated with non-conductive material such as organics or redox byproducts) than larger electrodes because it doesn't take as much material to coat the electrode surface. They are more difficult to fabricate and are hence more 
WSRC-RP-96-83

Page 4 of 6

expensive. These differences must be taken into account when evaluating the use of the electrode.

\section{CONCLUSION AND PATH FORWARD}

ADS has successfully implemented microelectrodes for use in $\mathrm{pH}$ measurements and acid base titrations. The microelectrode methods generate less than half the waste of the standard size electrodes. This change decreased the liquid waste generated from the titration methods by $60 \%$ and the waste generated from $\mathrm{pH}$ determinations by more than $90 \%$. The method mechanics are the same for both types of electrodes. The precision and accuracy of the data are relatively unchanged within the limits of the method. ADS is currently evaluating microelectrodes for use in the potentiometric and ion selective electrode methods performed in the lab. 
WSRC-RP-96-83

Page 5 of 6

Figure 1: pH Titration Curve for Total Hydroxide Measurement

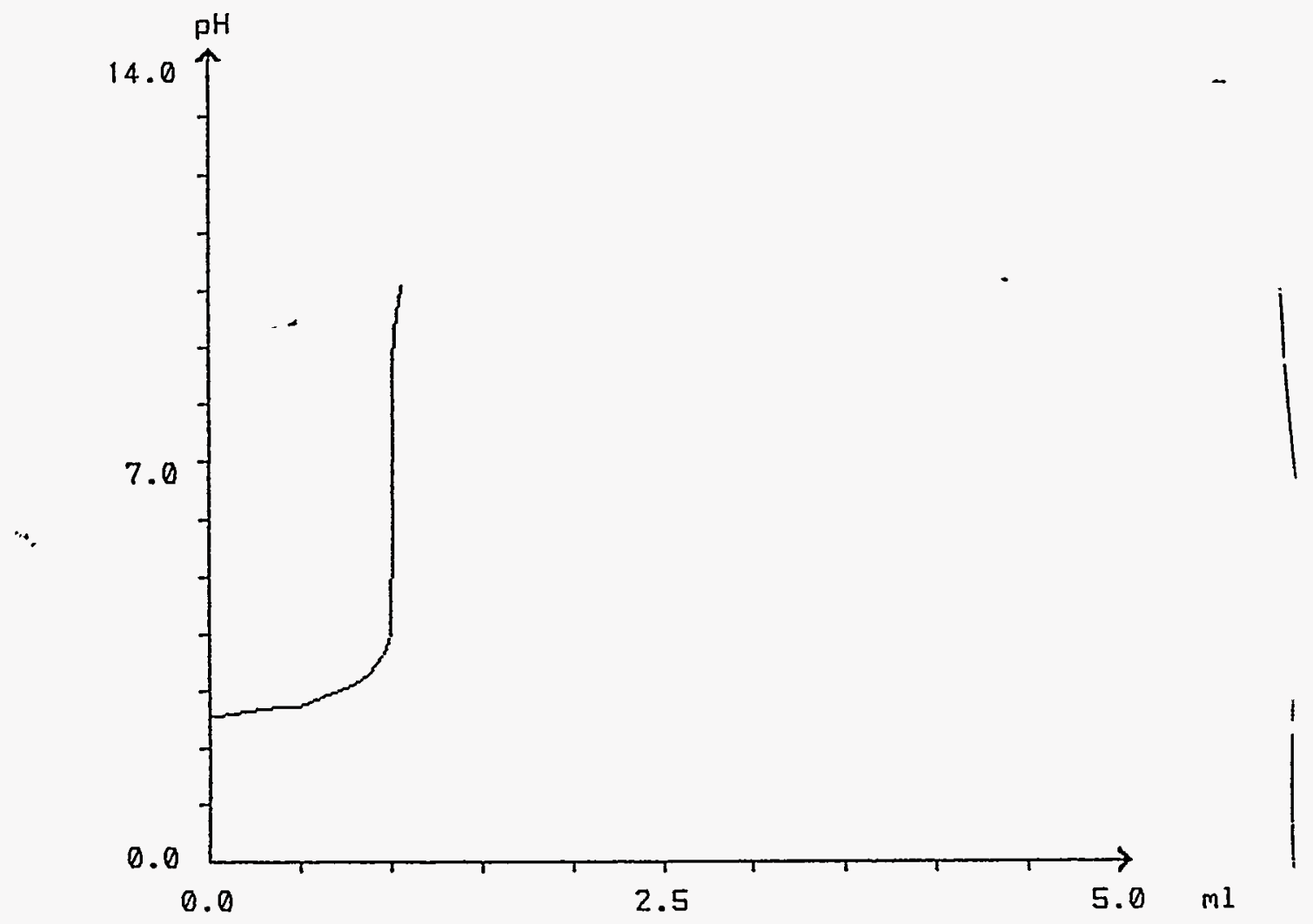

RADIOMETER TITRALAB DATE: $96-02-28 \quad 12: 41$

3 TOTAL ACID

IP

Sample number

1

$\begin{array}{lllcc}\text { Stack } & \text { Identification } & \text { Amount } & \text { Unit } & \text { Smp factor } \\ \text { No. } & \text { STD } & 0.1000 & \mathrm{ml} & 1.0000\end{array}$

Start pH: $\quad 2: 575$

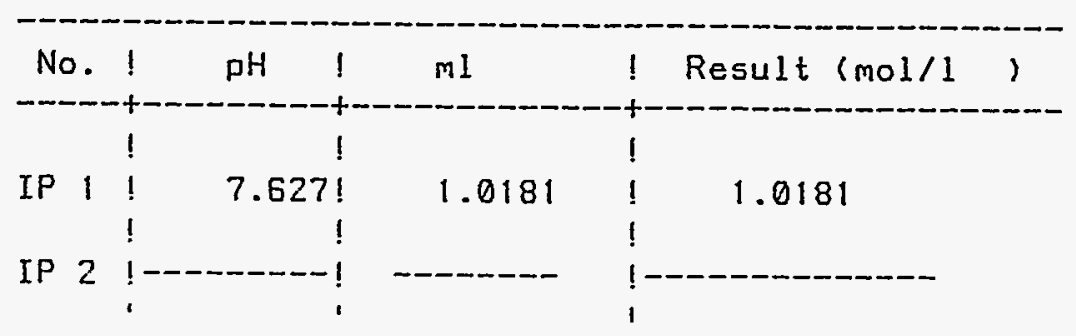


WSRC-RP-96-83

March 1, 1996

DISTRIBUTION:

TO: $\quad$ A.L. Blancett, 773-A

FROM: A.A. Ekechukwu, 773-A

CC: J.E. Young, 773-A

C.J. Coleman, 773-A

D.M. Ferrara, 773-A

L.M. Chandler, 772-3F

L.C. Johnson, 772-T

S.M. Dyer, 704-28S

R.B. Spencer, 703-33S

$\mathrm{K}$. Andringa, 773-41A

P.F. Cloessner, 773-A

M.A. Polochko, 773-A

J.C. Griffin, 773-A

SRTC Records (4) 